\title{
NO SE CERRARÁ
}

Ahora no me puedo acordar con qué motivo, hace ¿un par de cursos? se nos ocurrió a una compañera y a mí intentar visualizar un viejo diskette en el ordenador que Carmelo tenía en su despacho, porque no podíamos hacerlo ya en los nuestros, de última generación. Carmelo, entre la enfermedad y la jubilación, llevaba años sin regresar al que sería su último lugar de trabajo, al final del ala oeste del pasillo de Modernas, y por tanto, todos esos años sin abrir su ordenador personal. Fue encenderlo y aparecer en pantalla el siguiente aviso: "Este ordenador ha sido mal cerrado". Nos miramos y nos quedamos entre perplejos y sonrientes intentando interpretar aquel mensaje que desde no podía saberse cuándo estaba guardado para manifestarse en algún momento.

Se trataba de una advertencia de orden técnico, sí, pero también mucho más, o así nos quiso sonar (por sonarnos, nos sonaba incluso como una broma del propio Carmelo). El usuario de aquel ordenador no había clausurado nada, la sesión no se había cerrado en condiciones, había sido sólo un amago, una orden mal dada, una salida poco atenta al teclado, ¿le habría tan siquiera dado a "apagar equipo" o -ni eso- mas bien se lo había dejado encendido y lo apagó algún corte de red de los muchos producidos a los largo de los años?... quién podía saberlo... Bueno, hubiera pasado lo que hubiera pasado, el ordenador confiaba en el reinicio.

De hecho, se percibía en el tonito del aviso -"Este ordenador ha sido mal cerrado..." - un cierto enojo, una ligera amonestación, por lo dilatado de la espera, por haberse tenido que mantener el ordenador tanto tiempo en una situación de ínterin. En fin, que todo estaba como el último día que Carmelo, su usuario, había estado trabajando allí, tal y como lo había dejado (que no cerrado). No había transcurrido ni un segundo. Claro que ¿cómo transcurre el tiempo en el interior de un ordenador mal cerrado? Me imagino -es un decir- que como uno de esos "no tiempos" de la crítica de la ficción. ¿Y qué hicimos?, se preguntará el lector, pues volvimos a cerrarlo mal, lógicamente, quiénes éramos nosotros para cerrar lo que Carmelo no había cerrado. Y así seguirá, en el mejor de los casos.

Cerrar mal el ordenador es una forma de no cerrarlo. Los trabajos que encierra este volumen quisieran también estar mal (en)cerrados, pendientes de un reinicio continuo, como la memoria y magisterio de Carmelo Cunchillos Jaime, como Carmelo; sin clausura posible, sin que queramos acusar recibo de su desaparición.

\section{Bernardo Sánchez Salas}

Alumno 